\title{
PRECLINICAL STUDENTS' PERCEPTION TOWARDS FACTORS OF ACHIEVING MEDICAL COMPETENCE
}

\author{
Christine Tjahjadinata ${ }^{1}$, Natalia Puspadewi ${ }^{2}$, Elisabeth Rukmini ${ }^{3 *}$ \\ ${ }^{1}$ Program Studi Kedokteran, Fakultas Kedokteran dan IImu Kesehatan, Universitas Katolik Indonesia Atma Jaya, Jakarta - \\ INDONESIA \\ ${ }^{2}$ Medical Education Unit, Fakultas Kedokteran dan IImu Kesehatan, Universitas Katolik Indonesia Atma Jaya, Jakarta - INDONESIA \\ ${ }^{3}$ Medical Education Unit dan Prodi Farmasi, Fakultas Kedokteran dan Ilmu Kesehatan, Universitas Katolik Indonesia Atma Jaya, \\ Jakarta - INDONESIA
}

Submitted: 25 April 2019; Final Revision from Author: 14 October 2020; Accepted: 16 October 2020

\begin{abstract}
Background: Based on the existing research, medical competence achievements in DKI Jakarta's primary health care was lower than other provinces in Indonesia. Some of the competence achievements in preclinical years were also lower than the level of competence achievement in the Standard of Indonesian Doctor Competence, regardless the diseases are at the third and fourth levels. This research aimed at exploring the factors which influenced the competence achievement of the preclinical years based on student's perceptions.
\end{abstract}

Methods: The research was a descriptive analytic study with a qualitative approach using Focus Group Disscussion (FGD). Nine preclinical students of 2013 batch were chosen purposefully based on the recommendation from faculty members and students. Data were analyzed qualitatively using thematic analysis method.

Results: There are several factors that influence the competence achievement of the preclinical students. These included the factors of student, curriculum, faculty, environmental, and facility. There were four participants in the first meeting and five participants in the second meeting.

Conclusion: Based on student's perception, the factors which affect the competence achievements in preclinical years are student factors, curriculum factors, faculty factors, environmental factors, and facility factors.

Keywords: competence, medical education, preclinical, qualitative

\section{ABSTRAK}

Latar belakang: Berdasarkan riset yang telah ada, pencapaian kompetensi kedokteran di layanan kesehatan primer DKI Jakarta lebih rendah dibandingkan dengan provinsi lainnya di Indonesia. Beberapa pencapaian kompetensi mahasiswa preklinik pun masih berada di bawah target pencapaian kompetensi di SKDI, meskipun daftar penyakit tersebut berada pada level kompetensi yang tinggi, yaitu level 3 dan 4 . Tujuan penelitian ini untuk memperoleh gambaran faktor-faktor apa saja yang mempengaruhi pencapaian kompetensi kedokteran mahasiswa preklinik menurut persepsi mahasiswa.

Metode: Penelitian ini merupakan penelitian deskriptif analitik menggunakan pendekatan kualitatif dengan cara Focus Group Disscussion (FGD) terhadap 9 mahasiswa preklinik angkatan 2013 Fakultas Kedokteran dan

$\overline{\text { *corresponding author, contact: elisabeth.rukmini@atmajaya.ac.id }}$ 
Ilmu Kesehatan Universitas Katolik Indonesia Atma Jaya. Partisipan dipilih secara purposeful berdasarkan rekomendasi tim dosen dan kelompok mahasiswa. Analisis data kualitatif menggunakan analisis tematik.

Hasil: Menurut para responden, terdapat beberapa faktor yang mempengaruhi pencapaian kompetensi mahasiswa preklinik, yaitu faktor mahasiswa, kurikulum, dosen, lingkungan, serta fasilitas. Responden pada pertemuan pertama berjumlah 4 orang dan pada pertemuan kedua berjumlah 5 orang.

Kesimpulan: Berdasarkan persepsi mahasiswa, faktor yang mempengaruhi pencapaian kompetensi kedokteran mahasiswa preklinik meliputi faktor mahasiswa, kurikulum, dosen, lingkungan, dan fasilitas.

Kata kunci: kompetensi, pendidikan kedokteran, preklinik, kualitatif

\section{PRACTICE POINTS}

- Pencapaian kompetensi kedokteran mahasiswa preklinik sebagai indikator penting dalam persiapan mahasiswa memasuki proses pendidikan tahap klinik dipengaruhi oleh multifaktor.

- Faktor mahasiswa, kurikulum, dosen, lingkungan, serta fasilitas memiliki peran yang sama penting dalam pencapaian kompetensi mahasiswa preklinik yang lebih baik.

- Mahasiswa, dosen, maupun pihak penyelenggara pendidikan kedokteran dan penyusun kurikulum merupakan tokoh kunci dalam pelaksanaan pendidikan kedokteran yang efektif dan efisien.

\section{PENDAHULUAN}

Menurut penelitian Adisasmito dkk, ${ }^{1}$ DKI Jakarta masih memiliki beberapa pencapaian kompetensi kedokteran di layanan kesehatan primer yang lebih rendah apabila dibandingkan dengan provinsi lainnya, seperti Lampung, Pontianak, Bali, Makassar, dan Ternate. Kompetensi tersebut meliputi komunikasi efektif, keterampilan klinis, pengelolaan informasi, landasan ilmiah ilmu kedokteran, etika, moral, medikolegal profesional, dan keselamatan pasien. Berdasarkan data RISTEKDIKTI tahun 2018, beberapa universitas di DKI Jakarta masih memperoleh angka kelulusan Ujian Kompetensi Mahasiswa Program Profesi Dokter (UKMPPD) yang rendah dengan rata-rata $77.04 \% .^{2}$

Penelitian sebelumnya yang dilakukan oleh Tjahjadinata $\mathrm{dkk}^{3}$ pada mahasiswa preklinik angkatan 2013 di Fakultas Kedokteran dan Ilmu Kesehatan Universitas Katolik Indonesia Atma Jaya (FKIK UAJ) pun menunjukkan bahwa masih terdapat beberapa pencapaian kompetensi mahasiswa preklinik yang berada di bawah target pencapaian kompetensi di SKDI, meskipun daftar penyakit tersebut berada pada level kompetensi yang tinggi, yaitu level 3 dan 4. Rata-rata 36,01\%-60,55\% mahasiswa belum mencapai target pencapaian kompetensi pada SKDI.

Beberapa contoh pencapaian kompetensi kedokteran yang masih berada di bawah SKDI ialah pada bidang muskuloskeletal (79.01\%), psikiatri (70.44\%), dan reproduksi $(68.32 \%){ }^{3}$. Hal ini bertolak belakang dengan prevalensi penyakit yang masih banyak ditemukan di masyarakat, seperti prevalensi osteoporosis di Indonesia yang mencapai 32.3\% pada wanita dan $28.8 \%$ pada pria di atas 50 tahun, prevalensi depresi pada usia 15-24 tahun yang mencapai $6.2 \%$, dan anemia defisiensi besi pada kehamilan di Indonesia yang mencapai 50.5\%. ${ }^{4 \cdot 6}$

Oleh karena itu, peneliti pun merasa perlu untuk meneliti mengenai faktor-faktor apa saja yang dapat mempengaruhi tingkat pencapaian kompetensi kedokteran mahasiswa preklinik untuk melihat adanya potensi pengembangan kurikulum yang lebih baik lagi dengan mempertimbangkan faktorfaktor tersebut. Penelitian ini pun penting untuk dilakukan di fakultas kedokteran yang terletak di Jakarta untuk mengevaluasi pencapaian kompetensi 
mahasiswa kedokteran di Jakarta yang lebih rendah apabila dibandingkan dengan beberapa kota lainnya di Indonesia.

Mengingat pendidikan sarjana kedokteran di Indonesia terbagi menjadi 2 tahap yang berkelanjutan, yaitu tahap preklinik dan tahap klinik, maka penelitian mengenai faktor yang mempengaruhi pembelajaran mahasiswa preklinik juga penting dilakukan untuk membantu proses evaluasi kurikulum pada pendidikan mahasiswa preklinik dalam mempersiapkan proses pendidikan pada tahap klinik. Pada tahun-tahun pertama pendidikan kedokteran, mahasiswa akan diajarkan mengenai teori dan praktik ilmu kedokteran, sementara paparan klinis yang paling signifikan akan diajarkan pada tahun-tahun terakhir pendidikan kedokteran melalui berbagai situasi maupun simulasi klinis. Maka dari itu, pencapaian kompetensi pada level 3 dan 4 dapat mulai diraih sejak saat preklinik. ${ }^{3}$

Berdasarkan hal tersebut, penelitian ini dilakukan dengan tujuan untuk mengetahui faktor-faktor yang mempengaruhi pencapaian kompetensi mahasiswa preklinik di DKI Jakarta, khususnya di FKIK UAJ.

Penelitian dilakukan menggunakan metode penelitian kualitatif dengan Focus Group Disscussion (FGD) karena penelitian kualitatif lebih mampu memahami realitas yang kompleks seperti proses belajar mengajar mahasiswa preklinik dan lebih informatif dibandingkan data angka dalam penelitian kuantitatif. ${ }^{7,8}$ Selain itu, FGD merupakan metode penelitian kualitatif yang fleksibel, memiliki cakupan pendekatan keilmuan yang luas, dan dapat menampung lebih banyak informasi mengenai keinginan, kebutuhan, sudut pandang, dan pengalaman yang dikehendaki peserta secara komprehensif dengan waktu yang singkat melalui diskusi antar partisipan dan adanya arahan dalam diskusi melalui peran moderator dan pedoman FGD yang telah dibuat sebelumnya., ${ }^{9}$

Penelitian dilakukan terhadap 9 orang mahasiswa yang dipilih secara purposeful berdasarkan rekomendasi tim dosen dan kelompok mahasiswa. Sembilan partisipan tersebut terdiri dari 3 orang dengan pencapaian tingkat kompetensi di bawah SKDI, 3 orang sesuai dengan SKDI, hingga 3 orang yang melebihi target SKDI yang dapat mewakili opini mahasiswa secara menyeluruh.

\section{METODE}

Penelitian ini merupakan penelitian deskriptif analitik yang menggunakan pendekatan kualitatif dengan FGD untuk mengeksplorasi faktor-faktor yang berperan dalam pencapaian kompetensi mahasiswa. Penelitian dilaksanakan di FKIK UAJ yang beralamat di Jalan Pluit Raya 2, Pluit, Jakarta Utara sejak bulan Agustus 2016 dan penyusunan laporan selesai dilaksanakan pada bulan Mei 2017.

Kriteria inklusi untuk responden dalam penelitian ini meliputi mahasiswa preklinik angkatan 2013 FKIK UAJ yang telah melakukan pengisian kuesioner mengenai perspektif dirinya sendiri terhadap pencapaian tingkat kompetensi SKDI serta bersedia mengikuti FGD dan aktif dalam diskusi. Berdasarkan hasil kuesioner yang telah dibagikan kepada seluruh mahasiswa preklinik angkatan 2013 FKIK UAJ yang berjumlah 181 mahasiswa, maka peneliti memilih 9 mahasiswa dengan hasil perspektif pencapaian yang bervariasi, mulai dari 3 orang dengan pencapaian tingkat kompetensi yang sesuai dengan SKDI, 3 orang dengan pencapaian tingkat kompetensi di bawah SKDI, hingga 3 orang dengan pencapaian tingkat kompetensi melebihi target pencapaian kompetensi dalam SKDI.

FGD dilaksanakan dalam dua kali pertemuan karena adanya ketidaksesuaian jadwal antar para responden FGD. Pertemuan pertama dilakukan bersama 4 orang responden pada 19 Januari 2017 dan pertemuan kedua dilakukan bersama 5 orang responden pada 23 Januari 2017. Peneliti juga membuat panduan pertanyaan dan pelaksanaan FGD yang digunakan untuk memandu pelaksanaan diskusi.

Pengolahan data kualitatif menggunakan analisis tematik. Proses membaca verbatim, coding, kategorisasi, serta reduksi data kualitatif dilakukan oleh penulis pertama dan penulis kedua bersama seorang mahasiswi fakultas kedokteran yang tidak memiliki unsur kepentingan apa pun dalam penelitian ini atau pihak netral. Kami juga mengadakan pertemuan langsung untuk mendiskusikan perbedaan pendapat yang timbul 
dari hasil coding, kategorisasi, dan reduksi data yang telah dibuat sebelumnya oleh penulis pertama.

Penelitian ini sudah mendapatkan persetujuan ethical clearance dari Komisi Ethical Clearance Fakultas Kedokteran dan Ilmu Kesehatan Universitas Katolik Indonesia Atma Jaya (No. 11/08/KEPFKUAJ/2016). Sebelum melakukan FGD, peneliti terlebih dahulu memberikan penjelasan terkait tujuan dan teknis pelaksanaan penelitian diikuti dengan penandatanganan informed consent sebagai pernyataan persetujuan.

\section{HASIL DAN PEMBAHASAN}

Berdasarkan pengolahan data dalam penelitian ini didapatkan beberapa faktor yang mempengaruhi pencapaian kompetensi mahasiswa preklinik, yaitu faktor mahasiswa, faktor kurikulum, faktor dosen, faktor lingkungan, serta faktor fasilitas.

Faktor mahasiswa meliputi hal-hal yang bersifat individual, seperti pembelajaran mahasiswa saat preklinik, minat mahasiswa, waktu belajar, motivasi belajar, dan pengetahuan mahasiswa mengenai ilmu dasar kedokteran. Berdasarkan penelitian, mahasiswa dengan prior knowledge dan motivasi yang adekuat akan mendorong proses pembelajaran menjadi lebih baik dan pemahaman materi akan menjadi lebih mudah. ${ }^{11}$

Faktor kurikulum merupakan ketentuan pembelajaran yang diterapkan fakultas kedokteran. Kurikulum yang mendukung proses pembelajaran dengan komposisi teori dan praktik yang memadai akan mendorong mahasiswa untuk mencapai kompetensi yang diharapkan dalam proses pembelajaran. ${ }^{11}$

Faktor dosen meliputi hal-hal yang mempengaruhi proses mengajar mahasiswa, seperti kemampuan dosen dalam mengajar dan kecocokan dosen dengan mahasiswa. Tindakan, sikap, antusiasme, dan ketertarikan dosen dalam mengajar akan mempengaruhi mahasiswa secara tidak langsung dan berdampak pada hasil proses pembelajaran karena dosen merupakan role model bagi mahasiswa. ${ }^{11}$

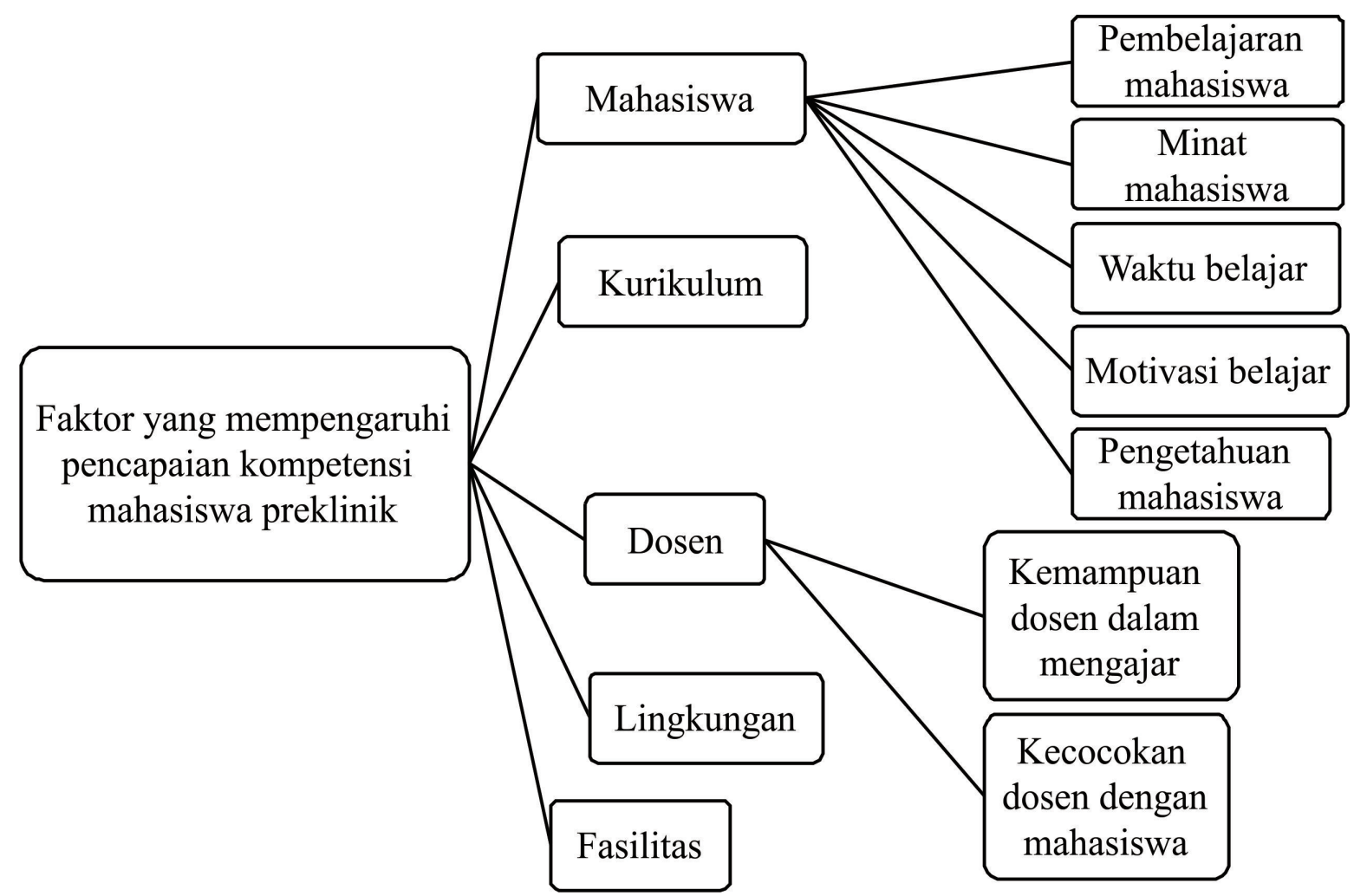

Gambar 1. Faktor-faktor yang mempengaruhi pencapaian kompetensi mahasiswa preklinik 
Sementara faktor lingkungan berkaitan dengan suasana belajar mahasiswa dan faktor fasilitas meliputi sarana dan prasarana yang digunakan dalam proses belajar mengajar mahasiswa dan dosen. Lingkungan dan sarana yang mendukung proses pembelajaran akan membangun motivasi mahasiswa dalam proses belajar mencapai kompetensi kedokteran yang diharapkan. ${ }^{12}$

\section{Faktor mahasiswa}

Faktor mahasiswa meliputi pembelajaran mahasiswa, minat mahasiswa, waktu belajar, motivasi belajar, serta pengetahuan mahasiswa. Proses pembelajaran mahasiswa preklinik telah dipusatkan pada penyakitpenyakit dengan tingkat kompetensi 3 dan 4 . Beberapa teori dan keterampilan diberikan sesuai dengan proporsi level penyakit di SKDI, seperti penjelasan materi anemia defisiensi besi yang diberikan secara mendalam hingga pemantauan hasil terapi dan penjelasan materi kanker yang dipusatkan pada deteksi dini. Namun demikian, tingkat pencapaian kompetensi mahasiswa preklinik kerap kali belum bisa mencapai tingkat kompetensi 4 karena proses pembelajaran yang masih hanya berdasarkan pada teori semata dan tidak berhadapan langsung dengan pasien.

“... pada preklinik itu lebih mengarah belajar teori dan patogenesis, manifestasi klinis. Namun untuk terapinya sendiri itu hanya sebatas teori dan belum melihat secara langsung. Nanti diharapkan kalo ketika sudah di klinik, sudah bisa terapi awal dan terapi yang selanjutnya seperti itu ...." (2H2)

Mahasiswa klinik pun memiliki kemampuan clinical reasoning yang lebih baik daripada mahasiswa preklinik karena sudah terpapar atau menangani pasien secara langsung sehingga melatih kemampuan mahasiswa dalam melakukan clinical reasoning dan pengolahan informasi terkait kasus yang dialami pasien untuk mendapatkan diagnosa yang tepat. ${ }^{13}$

“... untuk bisa mencapai maksimal di SKDI itu kita perlu pengalaman. Ga bisa cuma dengan baca textbook gitu meskipun bahan materi kuliah segala macem tetep ga bisa kalau misalnya belum berhadapan langsung dengan pasien ...." (1D5)
Proses pembelajaran dengan praktik langsung pada pasien tergolong dalam experiential learning, yaitu proses pembelajaran untuk memperoleh pengetahuan yang berasal dari pengalaman. ${ }^{3}$ Experiential learning mendukung mahasiswa dalam menerapkan pengetahuan dan pemahaman mereka terhadap suatu masalah atau situasi di dunia nyata dengan dibimbing oleh seorang fasilitator. Proses pembelajaran ini biasa dilakukan dalam bentuk studi kasus, penelitian, simulasi, maupun suatu percobaan di laboratorium..$^{14}$ Hasil dari proses pembelajaran ini cenderung lebih baik daripada pembelajaran yang hanya berdasarkan teori saja karena mahasiswa akan terus memperdalam pengetahuan mereka melalui latihan yang berulang dan refleksi dalam experiential learning. ${ }^{15}$

Minat mahasiswa dalam belajar pun berpengaruh terhadap proses pencapaian kompetensi mahasiswa preklinik. Minat sendiri dapat didefinisikan sebagai suatu kecenderungan hati yang tinggi terhadap sesuatu. ${ }^{16}$ Minat merupakan dasar dari perhatian dan pemahaman seseorang yang memiliki pengaruh besar terhadap segala kegiatan yang dilakukannya, sehingga seorang mahasiswa harus memiliki minat dalam belajar untuk mendapatkan proses dan hasil belajar yang optimal..$^{17,18}$ Minat seorang mahasiswa dapat berubah-ubah tergantung pada kebutuhan, emosi, pengalaman, dorongan dari orang tua dan keluarga, ketersediaan sumber pembelajaran, motivasi dalam belajar, serta cita-cita yang ingin dicapai mahasiswa di masa yang akan datang. ${ }^{19-21}$

“... kalau misalnya memang dokternya suka di bidang itu nanti berarti dokternya bakal banyak belajar, belajar lebih dalem, bakal lebih menguasai juga." (1D9)

"Kalau misalnya memang peminatannya di satu tempat pasti jadi lebih semangat, lebih seneng, lebih mudah untuk mempelajari hal-hal tertentu yang terkait sistem itu." (1W9)

Proses pencapaian kompetensi mahasiswa preklinik juga dipengaruhi oleh motivasi mahasiswa dalam belajar. Motivasi sendiri merupakan dorongan yang timbul pada diri seseorang secara sadar atau tidak sadar untuk melakukan suatu tindakan dengan 
tujuan tertentu. ${ }^{16}$ Salah satu motivasi mahasiswa preklinik dalam belajar ialah untuk menghadapi ujian. Semakin dekat dengan waktu ujian, maka mahasiswa akan cenderung lebih berusaha untuk mendalami materi yang sedang dipelajarinya agar kelak dapat mengerjakan ujian dengan baik.

Motivasi secara umum terbagi menjadi dua, yaitu motivasi intrinsik dan motivasi ekstrinsik. Motivasi intrinsik berasal dari dalam diri mahasiswa itu sendiri yang dapat menentukan tujuan pembelajaran, merencanakan pembelajaran, dan memantau proses pembelajaran. ${ }^{22,23}$ Salah satu tujuan pembelajaran mahasiswa ialah untuk memperoleh nilai yang baik dalam ujian. Motivasi intrinsik dapat ditingkatkan melalui berbagai cara, seperti dengan melakukan konseling kepada mahasiswa mengenai pentingnya proses pembelajaran, memberi kebebasan kepada mahasiswa untuk belajar apa yang diinginkannya, lebih memperhatikan perasaan mahasiswa dalam proses pembelajaran, serta menerapkan manajemen kelas yang baik untuk menunjang proses pembelajaran yang optimal. ${ }^{23}$

Motivasi intrinsik juga dipengaruhi oleh motivasi ekstrinsik yang berasal dari luar diri mahasiswa, contohnya reward atau penghargaan seperti beasiswa atau potongan uang kuliah yang diberikan oleh fakultas kepada mahasiswa yang berprestasi. Penghargaan yang demikian dapat berpengaruh secara signifikan terhadap motivasi dan hasil belajar mahasiswa. $^{3}$

Menurut para responden, waktu yang digunakan mahasiswa untuk belajar juga mempengaruhi pencapaian kompetensi mahasiswa preklinik. Proses pembelajaran yang dilakukan dalam waktu singkat di preklinik menyebabkan mahasiswa tidak mampu mempelajari semua penyakit yang terdapat di dalam SKDI secara mendalam dan lebih memusatkan proses pembelajaran pada penyakit-penyakit yang sering terjadi di masyarakat. Hal tersebut mengakibatkan mahasiswa kurang mendalami beberapa penyakit yang jarang terjadi di masyarakat, seperti penyakit autoimun dan penyakit kongenital.

"Karena kita juga belajarnya karena terburu oleh waktu juga kan makanya ga begitu paham ...." (2J6)
"Emang ga ada waktu untuk hafalin itu baca itu... saat ini dibagi jadi beberapa yang diprioritasin." (2M10)

Namun demikian, keterbatasan waktu pembelajaran tersebut dapat diatasi dengan sistem pembelajaran saat ini yang bersifat lebih mandiri. Sistem pembelajaran yang mulai beralih dari sistem pembelajaran Teacher Centered Learning (TCL) menjadi sistem pembelajaran Student Centered Learning (SCL) mengakibatkan terjadinya perubahan fokus pembelajaran dari yang semula berpusat pada dosen menjadi berpusat pada mahasiswa. Mahasiswa dalam sistem pembelajaran SCL diharapkan untuk mampu belajar secara aktif, baik secara mandiri maupun berkelompok untuk mencari beragam ilmu pengetahuan, informasi, dan teknologi yang dibutuhkan dalam proses pembelajaran. Pembelajaran yang aktif tidak terbatas pada pembelajaran saat kuliah atau kegiatan lain di dalam kampus, melainkan mahasiswa dapat memanfaatkan waktu luangnya yang lebih banyak di luar kampus untuk mencari beragam informasi yang tidak terbatas. ${ }^{24}$

Pengetahuan mahasiswa, baik pengetahuan dasar mengenai penyakit atau dasar fisiologis tentang suatu sistem organ turut memiliki peran dalam pencapaian kompetensi mahasiswa preklinik. Apabila pengetahuan dasar seorang mahasiswa sudah bagus mengenai penyakit yang sedang dipelajarinya, maka proses pembelajaran akan berlangsung dengan lebih baik dan lebih mudah dimengerti, sehingga pencapaian kompetensi kedokteran tersebut akan lebih cepat terpenuhi sesuai dengan tingkat pencapaian yang diharapkan di dalam SKDI. Pengetahuan mengenai SKDI juga penting dalam mempengaruhi pencapaian kompetensi seorang mahasiswa preklinik, karena semakin cepat seseorang mengetahui apa yang dimaksud dengan SKDI, maka akan semakin cepat pula ia dapat mempelajari penyakit-penyakit apa saja yang harus dikuasai untuk mencapai tingkat pencapaian kompetensi yang sesuai dengan SKDI.

"Jadi sebaiknya kalau e... dari awal masuk itu sudah diberikan daftar SKDI-nya supaya mahasiswa udah tau apa yang harus dikuasai, apa yang nggak, dan sebagainya." (2H7) 
Sebelum memasuki pembelajaran klinis tentang penyakit kedokteran, seorang mahasiswa harus memiliki konsep dan ilmu kedokteran dasar yang kuat. ${ }^{25}$ Tak hanya mahasiswa preklinik, dokter yang sudah lulus pun harus memiliki pengetahuan dasar kedokteran yang kuat agar kelak dapat menyelesaikan masalah kedokteran yang dihadapinya setiap hari dengan lebih baik. ${ }^{26}$

Proses pembelajaran mahasiswa sendiri sudah dapat digolongkan dalam proses pembelajaran orang dewasa atau adult learning. Proses pembelajaran ini merupakan salah satu bagian dari proses pembelajaran seumur hidup yang sangat luas dan beragam yang meliputi seluruh kegiatan belajar formal dan informal yang dilakukan oleh orang dewasa untuk memperoleh pengetahuan dan keterampilan baru setelah sebelumnya menyelesaikan pendidikan dan pelatihan awal. ${ }^{27,28}$ Proses pembelajaran orang dewasa menuntut setiap orang dewasa seperti mahasiswa untuk memiliki tujuan yang jelas dan kuat dalam proses pembelajaran, karena dengan mengetahui tujuan proses pembelajaran seperti target pencapaian kompetensi yang terdapat di dalam SKDI, maka motivasi mahasiswa dalam mempelajari materi tersebut pun akan meningkat dan hal ini pun menjadi salah satu karakteristik utama pembelajaran orang dewasa, yaitu proses pembelajaran yang berorientasi pada tujuan pembelajaran. ${ }^{3}$

\section{Faktor kurikulum}

Faktor kurikulum yang dimaksud oleh para responden mencakup berbagai macam sistem pembelajaran yang digunakan. Menurut sebagian responden, sistem blok yang digunakan saat ini di fakultas-fakultas kedokteran di Indonesia mengakibatkan proses pembelajaran berlangsung secara komprehensif, sehingga mahasiswa setelah selesai menjalankan pendidikan preklinik idealnya sudah dapat menguasai penyakit-penyakit dengan tingkat pencapaian kompetensi level 3 dan 4 secara teoritis. Sistem pembelajaran berupa kuliah juga dianggap oleh sebagian responden sebagai salah satu faktor yang berpengaruh dalam proses pencapaian kompetensi karena pada perkuliahan dipaparkan mengenai banyak hal yang berkaitan dengan berbagai penyakit, sehingga membantu mahasiswa dalam mempelajari dan menguasai berbagai penyakit yang terdapat di dalam SKDI. Tak hanya itu, para responden juga mengatakan bahwa kurikulum yang menekankan proses pembelajaran pada pengetahuan dasar seperti anatomi dan fisiologi dapat membantu mahasiswa dalam mempelajari berbagai penyakit dengan lebih mudah, karena apabila pengetahuan mengenai kondisi tubuh yang normal dikuasai dengan baik, maka akan lebih mudah pula untuk mempelajari kelainan yang terjadi pada tubuh tersebut, seperti pada berbagai penyakit dan kelainan.

\footnotetext{
"Menurut saya yang paling pengaruh itu adalah kuliah karena kuliah itu dijabarkan semua penyakitpenyakitnya." (2H6)

“... dengan sistem blok ini kan kita belajarnya kan secara komprehensif ... jadi dengan uda ada sistem blok ini, idealnya 3 dan 4 sudah dikuasai secara teoritis." (2J5)

“... kurikulumnya sendiri bener-bener harus dikuatin di fisio, di faalnya ... jadi kalau dasarnya ada, buat mempelajari yang salah akan lebih mudah dengan tahu yang bener tuh gimana." (1W10)
}

Kurikulum sendiri merupakan seperangkat rencana dan pengaturan mengenai capaian pembelajaran lulusan, bahan kajian, proses, dan penilaian yang digunakan sebagai pedoman dalam penyelenggaran program studi. Kurikulum pendidikan tinggi harus senantiasa diperbaharui sesuai dengan perkembangan kebutuhan dan IPTEK yang dituangkan dalam capaian pembelajaran. ${ }^{29}$ Seluruh kegiatan akademik di FKIK UAJ pun diselenggarakan secara terintegrasi dalam blok dan setiap blok akan mencakup berbagai hasil pembelajaran yang harus dicapai oleh mahasiswa setelah blok tersebut selesai dilaksanakan. Sistem pembelajaran dalam bentuk blok ini mengharapkan mahasiswa untuk mampu menguasai seluruh cakupan kompetensi dokter yang telah ditetapkan di dalam SKDI.

Kuliah terintegrasi seperti sistem blok merupakan kegiatan akademik yang bertujuan untuk memberikan materi atau ilmu pengetahuan yang sesuai dan berkaitan dengan berbagai materi lain yang relevan dengan tujuan pembelajaran blok 
tersebut. Pada kegiatan ini, seorang dosen yang kompeten dalam bidang atau materi pembelajaran tersebut akan mengajarkan berbagai pengetahuan kepada mahasiswa dalam bentuk kuliah. ${ }^{30}$

Kuliah dapat menjadi cara yang efektif dalam menyampaikan informasi atau ilmu pengetahuan kepada mahasiswa dalam jumlah besar dan biasanya berguna untuk menyampaikan informasi berupa latar belakang ilmu pengetahuan, berbagai gagasan dalam ilmu pengetahuan, dan konsep dasar ilmu pengetahuan. Namun demikian, kuliah kurang efektif apabila digunakan sebagai media promosi dari suatu pemikiran yang bertujuan untuk mengubah perilaku mahasiswa, karena proses pembelajaran dengan metode kuliah bersifat pasif dan berlangsung dalam waktu yang singkat, sehingga mahasiswa cenderung hanya menerima informasi yang diberikan dosen saat kuliah tanpa memiliki waktu yang cukup untuk mengolah informasi yang baru diterimanya, bertanya, ataupun memperjelas kesalahpahaman yang ada. ${ }^{3}$

Berdasarkan hasil penelitian yang dilakukan oleh Herdinta Yudaristy, Irfanuddin, dan Mutiara Budi Azhar ${ }^{30}$ di Universitas Sriwijaya didapatkan fakta bahwa ilmu dasar kedokteran sangat berguna dalam proses pembelajaran mahasiswa, baik sebagai ilmu pengetahuan dasar dalam kegiatan Problem Based Learning (PBL), ilmu untuk menjawab berbagai soal ujian, hingga sebagai dasar dalam proses pembelajaran ilmu klinis atau patologi. Penekanan dalam ilmu kedokteran dasar sendiri berpusat pada prinsipprinsip dasar ilmu kedokteran dan keterampilan praktis dalam pembelajaran keterampilan klinis.

Proses pembelajaran mahasiswa pun akan menjadi suatu pembelajaran yang bermakna atau meaningful learning apabila proses pembelajaran dilakukan dengan menghubungkan pengetahuan yang baru dipelajarinya dengan pengetahuan dasar yang sudah diperoleh mahasiswa dari pembelajaran sebelumnya. Pembelajaran yang bermakna ini akan mengakibatkan retensi pengetahuan menjadi lebih lama dan mahasiswa dapat lebih memahami daripada sekadar menghafal. Hasil pembelajaran sebelumnya akan kembali diingat dan setiap pengetahuan menjadi saling berhubungan, sehingga aplikasi ilmu dalam kehidupan nyata pun menjadi lebih mudah diterapkan. ${ }^{31}$ Kurikulum yang menekankan proses pembelajaran pada pengetahuan atau ilmu dasar kedokteran akan mampu menunjang proses pembelajaran mahasiswa di tahapan selanjutnya, seperti saat mempelajari ilmu klinis kedokteran.

\section{Faktor dosen}

Kemampuan dosen dalam mengajar dan kecocokan dosen dengan mahasiswa merupakan faktor dosen yang berpengaruh terhadap pencapaian kompetensi mahasiswa preklinik. Dosen yang ideal menurut para responden ialah dosen yang bukan hanya sekadar memberi ilmu dan membaca slide presentasi saat mengajar, melainkan dosen yang memiliki kompetensi yang cukup untuk mengajar, mengajar dengan memandang dari sudut perspektif mahasiswa, sharing pengalaman, bisa memberikan semangat dan motivasi pada mahasiswa untuk belajar, serta memberikan arahan dan penekanan materi pembelajaran yang penting untuk diketahui oleh mahasiswa, khususnya dalam mencapai kompetensi yang diharapkan dalam SKDI.

Selain itu, kecocokan cara mengajar dosen dan cara belajar mahasiswa juga berpengaruh dalam proses pencapaian kompetensi mahasiswa preklinik. Hal ini bersifat subjektif dan sangat bervariasi antar mahasiswa. Apabila mahasiswa merasa cocok diajarkan oleh dosen dengan suatu cara mengajar tertentu, maka hal tersebut cenderung akan mendorong mahasiswa untuk belajar lebih banyak dan lebih baik lagi, namun apabila mahasiswa merasa tidak cocok dengan cara mengajar dosen tertentu, maka mahasiswa akan cenderung malas untuk belajar bersama dosen tersebut.

“... dosen yang bukan cuma kasih ilmu pengetahuan, tapi dia juga kasih tau cara belajar... dosen yang sharing pengalaman itu bakal lebih membuat mahasiswanya pengen tahu dan belajar lebih lagi." (1D11)

“... ada beberapa dosen yang kayak ngajar pembawaannya tuh bikin semangat, bikin mahasiswa tuh mau dengerin. Biasanya tuh emang lebih masuk, lebih inget gitu ...." (1W9) 
Proses pembelajaran sendiri dapat diartikan sebagai suatu interaksi antara mahasiswa dengan dosen dalam rangka mencapai tujuan tertentu. Berdasarkan definisi tersebut, maka proses pembelajaran tidak hanya berlangsung satu arah, melainkan terjadi secara timbal balik antara dosen dan mahasiswa. ${ }^{32}$ Baik dosen maupun mahasiswa memiliki peran masing-masing yang dapat mempengaruhi proses pembelajaran mahasiswa.

Mahasiswa memiliki gaya belajar yang berbeda-beda. Gaya belajar adalah cara seseorang dalam menerima dan mengolah informasi. Menurut Flemming, gaya belajar ada empat macam, ada yang paling baik belajar dengan cara melihat atau visual, mendengar atau audio, membaca atau menulis, maupun dengan cara melakukan atau kinestetik. Hal demikian membuat dosen harus kreatif dalam memodifikasi cara mengajar atau membuat media pembelajaran yang sesuai dengan semua gaya belajar mahasiswa. ${ }^{33}$

Gaya mengajar dosen pun berbeda-beda. Terdapat empat tipe dosen dalam mengajar, yaitu tipe elementary yang lebih menekankan proses pembelajaran pada hal understanding, comprehension, dan memorizing pada mahasiswa, tipe intermediate yang lebih menekankan proses pembelajaran pada critical thinking dan doing, tipe advanced yang lebih menekankan proses pembelajaran pada problem solving, serta tipe creative yang akan mengajak mahasiswa untuk thinking out of the box. ${ }^{32}$ Setiap gaya mengajar dosen memiliki kekurangan dan kelebihan masing-masing, namun setiap dosen tetap harus menjadi fasilitator yang baik dalam proses pembelajaran mahasiswa.

Dosen pada era SCL tidak lagi berperan sebagai pusat pembelajaran melainkan bertugas sebagai fasilitator yang berperan dalam membantu mahasiswa untuk mengakses informasi dan mengaplikasikan ilmu pengetahuan dalam mengatasi masalah kehidupan sehari-hari. Dosen juga diminta untuk mengkaji kompetensi mata kuliah yang perlu dikuasai mahasiswa di akhir pembelajaran, merancang strategi dan lingkungan pembelajaran yang dapat menyediakan beragam pengalaman belajar yang diperlukan mahasiswa dalam rangka mencapai kompetensi yang dituntut mata kuliah, serta mengidentifikasi dan menentukan pola penilaian hasil belajar mahasiswa yang relevan dengan kompetensi yang akan diukur. ${ }^{24}$

Seorang dosen juga dapat meningkatkan kemampuan berpikir mahasiswa dengan menciptakan kegiatankegiatan pembelajaran yang lebih bervariasi seperti penalaran, pengambilan keputusan, refleksi diri, serta pembuatan kesimpulan dan pemecahan masalah. Kegiatan-kegiatan tersebut mendorong mahasiswa untuk terlibat secara kognitif dan emosional dalam tugas-tugas yang diberikan selama proses pembelajaran serta memungkinkan mahasiswa untuk mengembangkan strategi dalam mengatasi masalah dan bernegosiasi solusi dengan cara yang kolaboratif. ${ }^{3}$

Dosen pun harus menjadi penyaji materi yang baik dalam proses pembelajaran mahasiswa, seperti dalam kuliah. Saat menyajikan materi, seorang dosen harus berbicara dengan suara yang dapat terdengar jelas oleh semua mahasiswa yang mengikuti kuliah dan materi yang disajikan dalam kuliah harus bersifat relevan dengan kehidupan nyata, disusun menjadi suatu stuktur pengetahuan yang logis, serta mengaktifkan rasa ingin tahu mahasiswa dan pengetahuan mahasiswa akan pembelajaran sebelumnya. Dosen pun tidak disarankan untuk menyajikan materi hanya dengan membaca slide atau catatan presentasi saja. ${ }^{3} \mathrm{Hal}$ ini menunjukkan bahwa setiap dosen harus selalu melakukan peningkatan kualitas akan cara mengajarnya agar dapat menunjang proses pembelajaran mahasiswa dengan lebih baik lagi.

\section{Faktor lingkungan}

Faktor lingkungan seperti teman belajar bisa berperan sebagai faktor yang positif maupun negatif dalam proses pembelajaran mahasiswa. Teman yang bisa diajak untuk belajar bersama, mampu memberi masukan yang membangun semangat mahasiswa dalam belajar, dan bisa menjadi tempat berbagi cerita saat jenuh akan mengurangi stres mahasiswa dalam belajar dan meningkatkan proses pembelajaran untuk mencapai tingkat kompetensi tertentu dalam SKDI. Sedangkan teman yang memberikan tekanan dalam proses pembelajaran akan menjadi faktor negatif dalam proses pembelajaran mahasiswa, 
contohnya teman yang suka mengejek mahasiswa lain yang belajar lebih banyak daripada yang diharuskan dengan kata-kata yang tidak membangun seperti terlalu ambisius dalam belajar dan lainnya.

"... lingkungan yang kondusif buat belajar itu tuh mempengaruhi seseorang untuk belajar dan mau untuk mencari tau lebih dan cari tau selengkap-lengkapnya tentang sesuatu gitu. Ketika satu lingkungan ngecap seseorang yang rajin dan seseorang yang beneran mau belajar untuk kayak gitu, itu justru neken orang-orang untuk standarnya sama dengan orang yang katanya ambis gitu loh." (2M14)

Proses pembelajaran mahasiswa dalam era SCL adalah pembelajaran kolaboratif. Pembelajaran kolaboratif merupakan proses pembelajaran yang didasarkan pada hubungan sosial. Kegiatan kolaboratif biasanya didasarkan pada empat prinsip dasar, yaitu fokus pembelajaran pada mahasiswa, mengutamakan interaksi dan praktik, pembelajaran dalam kelompok, serta penyelesaian masalah yang didasarkan pada pendekatan kasus di kehidupan nyata. $^{34}$ Pembelajaran kolaboratif ini dapat meningkatkan dan mengembangkan kemampuan sosial dan keterampilan mahasiswa dalam belajar, serta dapat membantu mahasiswa dalam memperoleh pengetahuan mereka sendiri melalui pertukaran ide yang terjadi saat proses kolaborasi dilakukan. ${ }^{3}$

Interaksi antara mahasiswa dengan lingkungannya dapat menimbulkan hasil yang bermacam-macam, salah satunya ialah stres. Stres dapat bersifat positif (eustress) apabila tidak mengganggu dan memberikan perasaan semangat, namun dapat pula bersifat negatif (distress) apabila bersifat merusak dan merugikan orang yang bersangkutan, seperti menimbulkan gangguan tidur (insomnia), mudah marah, sulit berkonsentrasi, hingga hilangnya kepercayaan terhadap orang lain. ${ }^{35}$ Stres juga berdampak terhadap lebih dari satu aspek individu, yaitu fisik, kognitif, emosi, dan perilaku. Salah satu contoh dampak stress terhadap aspek fisik ialah rasa kelelahan dan lemas saat beraktivitas sehari-hari. ${ }^{36}$

Stres pada mahasiswa dapat berasal dari empat macam sumber, yaitu interpersonal atau hubungan dengan orang lain, intrapersonal atau stressor dari dalam diri sendiri, akademik atau aktivitas perkuliahan, dan lingkungan atau hal lain di luar akademik. ${ }^{36}$ Stres sendiri dapat muncul karena adanya ketidakmampuan mahasiswa dalam beradaptasi atau menyesuaikan diri dengan lingkungannya. Mahasiswa dengan penyesuaian diri yang buruk terhadap tuntutan akademik akan memiliki kecenderungan stres yang tinggi. ${ }^{37}$ Oleh karena itu diperlukan proses penyesuaian yang baik dari mahasiswa terhadap segala situasi yang terjadi dalam proses pembelajarannya, termasuk dalam memenuhi tuntutan akademik dan menghadapi tekanan dari lingkungan sekitar.

Banyak peran yang dapat mempengaruhi terjadinya stres pada mahasiswa, mulai dari teman, dosen, hingga orang tua. Namun demikian, peran teman adalah peran yang paling berpengaruh terhadap stres mahasiswa karena mahasiswa memiliki kedekatan yang lebih tinggi terhadap temannya dibandingkan dengan orang tua maupun dosen. ${ }^{38}$

Teman bagi mahasiswa adalah sumber kasih sayang, simpati, pengertian, serta tempat saling berbagi pengalaman dan tempatuntuk mencapai otonomidan independensi. Mahasiswa memiliki kecenderungan untuk mengadopsi informasi yang diperoleh dari temannya tanpa memiliki sumber informasi lain yang lebih dapat dipercaya. Oleh karena itu, teman dapat membawa mahasiswa ke arah positif maupun negatif. Lingkungan pertemanan mahasiswa yang buruk akan membuat mahasiswa cenderung berbuat hal-hal yang bersifat negatif, sedangkan lingkungan pertemanan yang baik akan memberikan dampak positif bagi mahasiswa. ${ }^{38}$

\section{Faktor fasilitas}

Faktor fasilitas yang menjadi faktor penunjang dalam proses pembelajaran mahasiswa juga mempengaruhi proses pencapaian kompetensi mahasiswa preklinik. Salah satu fasilitas yang memberikan pengaruh cukup besar ialah ruang pembelajaran. Menurut para responden, ruang kelas yang baik ialah ruang kelas yang tidak terlalu padat dengan mahasiswa dan memiliki akses penglihatan ke layar presentasi atau papan tulis yang memadai untuk seluruh mahasiswa di dalam kelas. Hal tersebut dikarenakan tidak 
semua mahasiswa dapat duduk di barisan depan saat kelas berlangsung, sehingga tidak semua mahasiswa memiliki akses penglihatan yang memadai di dalam kelas.

Menurut para responden, mahasiswa yang duduk di bagian belakang kelas cenderung hanya fokus pada bagian awal kuliah saja, kemudian menjadi semakin tidak fokus menjelang akhir jam perkuliahan, sehingga akan lebih baik apabila ukuran kelas diperkecil, yang awalnya berskala besar seperti 200 orang menjadi skala yang lebih kecil seperti 100 orang saja agar semua mahasiswa dapat memiliki akses penglihatan yang memadai saat melihat ke arah layar presentasi atau papan tulis dan menjadi lebih fokus dalam proses pembelajaran guna mencapai tingkat kompetensi yang diharapkan dalam SKDI.

“... saran saya sih kelasnya jangan terlalu besar gitu biar kitanya bisa lebih fokus gitu... kalau misalnya kita dapet tempat duduk yang udah di pinggir, paling belakang, nanti kan kita pasti kayak awal doang gitu bisa fokus, nanti lama kelamaan fokusnya udah kemana-mana ...." (1J13)

Fasilitas penunjang untuk proses pembelajaran saat kuliah juga perlu dipersiapkan dengan baik, khususnya dalam hal audiovisual, microphone bersuara jernih, serta akses yang baik dari semua mahasiswa untuk melihat layar presentasi dan papan tulis saat kuliah berlangsung. ${ }^{3}$ Apabila terdapat kualitas fasilitas yang buruk dalam menunjang proses perkuliahan, maka proses pembelajaran akan terganggu dan mengakibatkan mahasiswa tidak dapat memperoleh pemahaman yang baik terhadap materi perkuliahan, khususnya mahasiswa yang tidak dapat mendengar suara dosen atau melihat layar presentasi dan papan tulis dengan baik.

Jumlah mahasiswa yang terlalu banyak dalam suatu ruang kuliah tidak akan menciptakan proses belajar mengajar yang efektif. ${ }^{30}$ Lingkungan kelas dapat mempengaruhi konsentrasi mahasiswa dalam proses pembelajaran, sehingga ruang kelas yang terlalu besar cakupan mahasiswanya, seperti 200 orang perlu dipecah menjadi beberapa kelas yang lebih kecil agar tercipta suasana belajar mengajar yang lebih kondusif. ${ }^{3}$
Namun demikian, tidak ada panduan yang jelas untuk menentukan jumlah mahasiswa yang ideal dalam sebuah kelas besar karena hal tersebut tergantung pada kemampuan dosen dalam mengajar. Dosen dengan kemampuan mengajar yang baik seperti memiliki kemampuan dalam menganalisa dan menguasai situasi kelas dapat memberikan pengajaran yang baik kepada lebih banyak mahasiswa dan begitu pula sebaliknya. ${ }^{39}$ Maka dari itu, jumlah mahasiswa dalam suatu kelas pun perlu disesuaikan dengan kemampuan dosen yang mengajar di kelas tersebut. Apabila jumlah mahasiswa dalam suatu kelas dianggap terlalu banyak, maka sebaiknya jumlah mahasiswa dalam kelas tersebut dipecah menjadi beberapa kelas yang lebih kecil agar proses belajar mengajar dapat berlangsung dengan lebih efektif.

Keterbatasan atau limitasi dari penelitian ini adalah subjek penelitian yang sangat homogen karena hanya mengambil sampel dari satu angkatan mahasiswa di FKIK UAJ. Dengan demikian, perlu dilakukan penelitian lanjutan di fakultas kedokteran lain di Indonesia sebelum melakukan generalisasi hasil dari penelitian ini.

\section{KESIMPULAN}

Pencapaian kompetensi kedokteran mahasiswa preklinik merupakan indikator penting dalam mengevaluasi persiapan mahasiswa untuk memasuki proses pendidikan pada tahap klinik. Berdasarkan persepsi mahasiswa, terdapat lima faktor penting yang mempengaruhi pencapaian kompetensi kedokteran mahasiswa preklinik, meliputi faktor mahasiswa, kurikulum, dosen, lingkungan, serta fasilitas yang dapat dikembangkan guna menciptakan pencapaian kompetensi yang lebih baik.

Pembelajaran mahasiswa, minat mahasiswa, waktu belajar, motivasi belajar, serta pengetahuan mahasiswa merupakan faktor individual yang berpengaruh dalam proses pembelajaran. Berbagai macam sistem pembelajaran yang digunakan dalam fakultas kedokteran serta kemampuan dosen dalam mengajar dan kecocokan dosen dengan mahasiswa juga dinilai penting dalam menunjang proses pembelajaran mahasiswa yang efektif dan efisien. 
Faktor lingkungan seperti teman belajar dan fasilitas yang menunjang proses pembelajaran juga dapat berperan sebagai faktor positif maupun negatif dalam proses pencapaian kompetensi mahasiswa preklinik.

\section{SARAN}

Peneliti merekomendasikan beberapa saran yang dapat dipertimbangkan dalam dunia pendidikan kedokteran di Indonesia. Peneliti menyarankan agar dilakukan peningkatan kualitas pada faktorfaktor yang berperan dalam proses pembelajaran mahasiswa, khususnya pada peningkatan kemampuan dosen dalam mengajar terutama untuk capaian kompetensi 3 dan 4. Hal ini dapat dilakukan dengan survei terlebih dahulu mengenai kriteria dosen ideal yang diharapkan mahasiswa maupun kriteria ideal berdasarkan teori yang sesuai dengan situasi dan kondisi fakultas kedokteran setempat. Kualitas fasilitas yang digunakan dalam proses pembelajaran agar sesuai dengan kebutuhan mahasiswa dalam menciptakan ruang belajar yang kondusif dan penyusunan kurikulum yang sesuai dengan kebutuhan proses pembelajaran mahasiswa dan tuntutan perkembangan zaman. Sebaiknya dilakukan pula penelitian lanjutan dari penelitian ini, khususnya mengenai faktor-faktor yang berperan dalam proses pembelajaran mahasiswa preklinik, terutama di fakultas-fakultas kedokteran lainnya di seluruh Indonesia serta mengenai bagaimana dan seberapa besar peran tiap faktor dalam proses pembelajaran mahasiswa preklinik.

\section{UCAPAN TERIMA KASIH}

Terima kasih kami ucapkan bagi Pricilia Friska, mahasiswi angkatan 2014 dari FKIK UAJ yang telah membantu proses pengumpulan dan pengolahan data bersama penulis pertama dan kedua. Terima kasih juga untuk para perwakilan mahasiswa angkatan 2013 dari FKIK UAJ yang telah membantu penulis dalam mengumpulkan data penelitian ini.

\section{DEKLARASI KEPENTINGAN}

Para penulis mendeklarasikan bahwa tidak terdapat konflik kepentingan apapun terkait studi pada naskah ini.

\section{KONTRIBUSI PENULIS}

Christine Tjahjadinata - berkontribusi sebagai perancang dan pelaksana penelitian, serta penulis naskah penelitian.

Natalia Puspadewi - berkontribusi sebagai ide awal penelitian dan pembimbing dalam perancangan dan pelaksanaan penelitian, serta penulisan naskah penelitian.

Elisabeth Rukmini - berkontribusi sebagai mentor desain, pelaksanaan penelitian dan penulisan naskah penelitian.

\section{DAFTAR PUSTAKA}

1. Adisasmito W, Purwantyastuti, Djuwita R, Thabrany H, Iljanto S, Kamso S, et al. Persepsi stakeholders tentang kompetensi dokter di layanan kesehatan primer. Maj Kedokt Indon. 2010; 60: 15-21.

2. Kementerian Riset, Teknologi, dan Pendidikan Tinggi. Potret Pendidikan Kedokteran di Indonesia. 2018

3. Tjahjadinata C. Gambaran pencapaian kompetensi penyakit kedokteran level 3 dan 4 mahasiswa preklinik angkatan 2013 di Fakultas Kedokteran dan Ilmu Kesehatan Unika Atma Jaya [skripsi]. Jakarta: Unika Atma Jaya; 2017.

4. Pusat Data dan Informasi Kementerian Kesehatan Republik Indonesia. InfoDATIN Data dan Kondisi Penyakit Osteoporosis di Indonesia. 2015.

5. Pusat Data dan Informasi Kementerian Kesehatan Republik Indonesia. InfoDATIN Situasi Kesehatan Jiwa di Indonesia. 2019.

6. Anggraini DD, Purnomo W, Trijanto B. Interaksi Ibu Hamil dengan Tenaga Kesehatan dan Pengaruhnya Terhadap Kepatuhan Ibu Hamil Mengonsumsi Tablet Besi (Fe) dan Anemia di Puskesmas Kota Wilayah Selatan Kota Kediri. Buletin Penelitian Sistem Kesehatan. 2018; 21(2): 82-89.

7. Almeida F, Faria D, Queiros A. Strengths and Limitations of Qualitative and Quantitative Research Methods. European Journal of Education Studies. 2017; 3: 369-387. 
8. Shakouri N. Qualitative Research: Incredulity Toward Metanarrativeness. Journal of Education and Human Development. 2014; 3(2): 671-680.

9. Ridlo IA, Putri NK, Intiasari AD, Sandra C, FirdausiNJ, Adriansyah, et al. FGD Dalam Penelitian Kesehatan. 2018.

10. Paramita A, Kristiana L. Teknik Focus Group Disscussion Dalam Penelitian Kualitatif. Buletin Penelitian Sistem Kesehatan. 2013; 16(2): 117127.

11. Fawzia FN, Probandari A, Suyatmi. Persepsi Mahasiswa Terhadap Faktor Penunjang Pembelajaran Dalam Skills Lab. Nexus Pendidikan Kedokteran dan Kesehatan. 2017; 6(1): 16-29.

12. Saputra O, Lisiswanti R. Faktor-faktor yang Mempengaruhi Keberhasilan Pembelajaran Keterampilan Klinik di Institusi Pendidikan Kedokteran. Juke Unila. 2015; 5(9): 104-109.

13. Pujiati. The Difference in clinical reasoning competence between pre-clinical students and clinical students on pediatric tropical disease cases. Sains Medika. 2015; 6: 25-29.

14. Wurdinger DD, Carlson JA. Teaching for experiential learning: Five approaches that work. Lanham, MD: Rowman \& Littlefield Education; 2010.

15. Faculty Innovation Center, The University of Texas at Austin. Experiential learning defined [Internet]. [cited 2017 Jun 14]. Available from: https://facultyinnovate.utexas.edu/teaching/ strategies/overview/experiential-learning.

16. Pusat Bahasa Departemen Pendidikan Nasional. Kamus Bahasa Indonesia [Internet]. [cited 2017 Jun 10]. Available from: https://kbbi. kemdikbud.go.id/

17. Darmadi. Kemampuan dasar mengajar. Bandung: Alfabeta; 2009.

18. Johnson EB. Contextual teaching and learning: Menjadikan kegiatan belajar-mengajar mengasyikkan dan bermakna. Setiawan I, penerjemah; Sitompul I, editor. Bandung: Mizan Learning Center (MLC); 2007. Terjemahan dari: Contextual Teaching and Learning: What It is and Why It's Here to Stay.
19. Santoso G. Fundamental metodologi penelitian kuantitatif dan kualitatif. Jakarta: Prestasi Pustaka; 2008.

20. Fitriya SM. Minat belajar mahasiswa ditinjau dari intensitas perhatian orang tua dan ketersediaan sumber belajar pada mahasiswa FKIP Universitas Muhammadiyah Surakarta [skripsi]. Surakarta: Universitas Muhammadiyah Surakarta; 2013.

21. Fitria H, Yani EA. Faktor-faktor yang mempengaruhi minat mahasiswa memilih Perguruan Tinggi Ekonomi Islam (Studi kasus: STEI SEBI). Jurnal Ekonomi dan Perbankan Syariah. 2014; 99-130.

22. Sumar WT, Razak IA. Strategi pembelajaran dalam implementasi kurikulum berbasis soft skill. Ed ke-1. Yogyakarta: Deepublish; 2016.

23. Santrock J. Educational psychology. Ed ke-5. New York: McGraw-Hill; 2011.

24. Kurdi FN. Penerapan student-centered learning dari teacher-centered learning mata ajar ilmu kesehatan pada program studi penjaskes. Forum Kependidikan. 2009; 28: 108-113.

25. Spencer AL, Brosenitsch T, Levine AS, Kanter SL. Back to the basic sciences: An innovative approach to teaching senior medical students how best to integrate basic science and clinical medicine. Academic Medicine. 2008; 83: 662669.

26. Maadawi ZME. The role of e learning in integration of basic \& clinical medical sciences, complete blood count (CBC) e-learning course, a case study from Kasr Alainy School of Medicine, Cairo University. 2010.

27. Brooks G, Burton M. European adult learning glossary, level 1. London: National Research and Development Centre for Adult Literacy and Numeracy; 2008.

28. Study on European terminology in adult learning for a common language and common understanding and monitoring of the sector. London: National Research and Development Centre for Adult Literacy and Numeracy; 2010.

29. Kementerian Riset, Teknologi, dan Pendidikan Tinggi. Panduan penyusunan kurikulum pendidikan tinggi. 2016. 
30. Yudaristy H, Irfanuddin, Azhar MB. Persepsi mahasiswa dan dosen tentang ketercapaian kompetensi dasar dan klinis pendidikan dokter di Fakultas Kedokteran Universitas Sriwijaya. Jurnal Kedokteran dan Kesehatan. 2014; 1: 25 33.

31. Vallori AB. Meaningful learning in practice. Journal of Education and Human Development. 2014; 3: 199-209.

32. Suwarni E. Hubungan gaya mengajar dosen dalam proses pembelajaran dengan motivasi belajar mahasiswa Fakultas Psikologi dan Pendidikan Universitas Al Azhar Indonesia. Jurnal Al-Azhar Indonesia Seri Humaniora. 2012; 1: 246-256.

33. Saputra O, Lisiswanti R. Faktor-faktor yang mempengaruhi ketertarikan mahasiswa dalam kelas besar. Juke Unila. 2015; 5(9): 115-118.

34. Collaborative learning: Group work [Internet]. [cited 2017 Jun 07]. Available from: https:// www.cte.cornell.edu/teaching-ideas/engagingstudents/collaborative-learning.html
35. Lumonga N. Depresi tinjauan psikologis. Jakarta: Kencana; 2009.

36. Musabiq SA, Karimah I. Gambaran Stress dan Dampaknya Pada Mahasiswa. Insight. 2018; 20(2): 75-83.

37. Christyanti D, Mustami'ah D, Sulistiani W. Hubungan antara penyesuaian diri terhadap tuntutan akademik dengan kecenderungan stres pada mahasiswa Fakultas Kedokteran Universitas Hang Tuah Surabaya. INSAN. 2010; 12: $153-159$.

38. Sutjiato M, Kandou GD, Tucunan AAT. Hubungan faktor internal dan eksternal dengan tingkat stres pada mahasiswa Fakultas Kedokteran Universitas Sam Ratulangi Manado. JIKMU. 2015; 5: 30-42.

39. Hansen M. Right-sizing the classroom: Making the most of great teachers [paper]. Washington, D.C.: CALDER; 2014. 